\title{
Recognizing and supporting morally injured ICU professionals during the COVID-19 pandemic
}

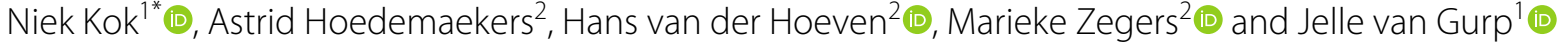

๑ 2020 Springer-Verlag GmbH Germany, part of Springer Nature

Dear Editor,

The COVID-19 pandemic is producing a maelstrom of morally distressing and potentially morally injurious events (pMIEs). PMIEs are defined as "perpetrating, failing to prevent, bearing witness to, or learning about acts that transgress deeply held moral beliefs and expectations" [1]. Moral distress, which occurs when intensive care unit (ICU) professionals cannot fulfill their moral requirements due to internal or contextual constraints, can fade over time. However, moral injury, a concept originating in military psychology, signifies a durable mental wound characterized by symptoms such as guilt, shame, existential or moral conflict, a loss of trust in goodness, moral detachment and/or moral disorientation [1-3]. A person becomes morally injured if exposed to repeated incidents of moral distress or due to a single egregious violation of morality.

Particularly in public health disasters, it is important to recognize moral injury with ICU professionals apart from post-traumatic stress disorder (PTSD) and the aforementioned moral distress. Moral injury, moral distress and PTSD differ with regard to etiology and consequences (see Table 1). PTSD does not necessarily involve guilt, shame, moral conflict or disorientation. The term "moral injury" signifies a deep mental wound, as opposed to a physiological or characterological disorder. Moral injury and PTSD can, however, be comorbid, and both may lead to avoidance symptoms, substance abuse and increased risk of suicide [3].

\footnotetext{
*Correspondence: niek.kok@radboudumc.nl

${ }^{1}$ IQ healthcare, Radboud University Medical Center, Nijmegen, The Netherlands
}

Full author information is available at the end of the article
During the COVID-19 pandemic, ICU professionals who participated in informal interviews and peer support consultations expressed events akin to pMIEs. Professionals described cases in which quality of care and basic care duties were compromised due to being responsible for a large volume of COVID-19 patients. Professionals reported feelings of disorientation, worry, a loss of control and powerlessness. Many professionals explained that because all COVID-19 patients suffer from the same disease and receive similar treatment, and due to restrictions on family visits, patients seemingly become "bodies" without context. Professionals, moreover, sometimes had to act while being confronted with the almost impossible choice between safe working conditions and quality of patient care.

The COVID-19 surge demands from ICUs to commit to long-term mental and moral support, as moral injury and a severe loss of moral integrity does not easily or quickly dissolve. Efforts are needed to prevent harm to individual professionals and substantial turnover in a highly qualified workforce.

First, we recommend ICUs to set up peer support mechanisms that take into account the needs and wishes of professionals. Generally, intensive care attracts perfectionists who may experience moral demands as especially stringent [4]. Peers should encourage professionals to facilitate self-forgiveness and start re-integrating moral transgressions into their moral code and accept that good persons sometimes, out of necessity, act badly. Since guilt and shame are not easily addressed, peers should aim for building long-lasting working relationships.

Second, we advise to stimulate grassroots dialogues on moral requirements in pandemic times. Small-group ethical deliberations help professionals explicate the values

\section{Springer}


Table 1 Differences between moral injury, moral distress and PTSD $[2,3,5]$

Moral distress Moral injury $\quad$ PTSD

\begin{tabular}{|c|c|c|c|}
\hline Cause or etiology & $\begin{array}{l}\text { Inability to act according to core } \\
\text { moral values or obligations due to } \\
\text { internal (e.g., a conscientious objec- } \\
\text { tion) or contextual constraints (e.g., } \\
\text { restrictions on family visits; resource } \\
\text { scarcity) }\end{array}$ & $\begin{array}{l}\text { Exposure to repeated incidents of moral } \\
\text { distress or due to a single egregious } \\
\text { violation of morality }\end{array}$ & $\begin{array}{l}\text { During a traumatic event (e.g., experiencing } \\
\text { war, being raped), regular physiological } \\
\text { stress responses (hyperarousal, increased } \\
\text { epinephrine, increased blood flow to } \\
\text { muscles) become amplified, and stimuli } \\
\text { reminiscent of the trauma trigger the } \\
\text { elevated stress state }\end{array}$ \\
\hline Symptomatology & $\begin{array}{l}\text { Feelings of powerlessness, unfairness, } \\
\text { frustration, anger or anxiety }\end{array}$ & $\begin{array}{l}\text { Persisting feelings of guilt and/or shame, } \\
\text { loss of trust in goodness, moral detach- } \\
\text { ment, moral disorientation, re-experi- } \\
\text { encing the MIE }\end{array}$ & $\begin{array}{l}\text { Unwanted upsetting memories, nightmares, } \\
\text { emotional distress or physical reactivity } \\
\text { after exposure to traumatic reminders, re- } \\
\text { experiencing the traumatic event }\end{array}$ \\
\hline Understanding & Maybe temporary, episode of distress & Hard to resolve, mental wound & Physiological or mental disorder \\
\hline Consequences & $\begin{array}{l}\text { If it dissipates over time, one's moral } \\
\text { framework remains intact. Repeated } \\
\text { or persistent distresses lead to pro- } \\
\text { fessional dissatisfaction, moral injury, } \\
\text { decompensation and burn-out }\end{array}$ & $\begin{array}{l}\text { Demoralization, erosion of one's moral } \\
\text { or spiritual framework, self-blame or } \\
\text { harm, avoidance of morally conflicting } \\
\text { thoughts and feelings, social isolation or } \\
\text { alienation }\end{array}$ & $\begin{array}{l}\text { Avoidance of trauma-related thoughts, } \\
\text { feelings or reminders, decreased interest in } \\
\text { activities, hypervigilance, risky or destruc- } \\
\text { tive behavior, and difficulty in concentrat- } \\
\text { ing and/or sleeping }\end{array}$ \\
\hline $\begin{array}{l}\text { Examples in ICU } \\
\text { practice }\end{array}$ & $\begin{array}{l}\text { An intensivist worries about having } \\
\text { compromised the quality of patient } \\
\text { care in his daily round as he was } \\
\text { only able to examine half of the } 45 \\
\text { COVID-19 patients he was responsi- } \\
\text { ble for; a fellow describes feelings of } \\
\text { unfairness for compromising quality } \\
\text { of care for non-COVID-19 patients, } \\
\text { some of whom are in a worse condi- } \\
\text { tion than COVID-19 patients }\end{array}$ & $\begin{array}{l}\text { A nurse has care duties for more patients } \\
\text { than usual and develops the habit of, } \\
\text { at the beginning of her shift, apologiz- } \\
\text { ing to COVID-19 patients for not being } \\
\text { able to provide them with the care she } \\
\text { feels she ought to provide due to time } \\
\text { constraints; an intensivist described, for } \\
\text { the first time in her career, feeling guilty } \\
\text { for blaming patients for having caught } \\
\text { the virus }\end{array}$ & $\begin{array}{l}\text { When asked which private affairs have } \\
\text { recently had an impact on one's working } \\
\text { life, an ICU professional expresses ongoing } \\
\text { emotional distress with experiencing abuse } \\
\text { as a child }\end{array}$ \\
\hline
\end{tabular}

a Morally injurious event

and principles at stake and clarify personally felt moral requirements and frameworks. Recognizing the wound is the first step out of moral disorientation and detachment.

\section{Author details}

${ }^{1}$ IQ healthcare, Radboud University Medical Center, Nijmegen, The Netherlands. ${ }^{2}$ Department of Intensive Care, Radboud University Medical Center, Nijmegen, The Netherlands.

\section{Author contributions}

All authors contributed to the study conception and design. Acquisition, analysis and interpretation of the data were performed by Niek Kok, Astrid Hoedemaekers, Marieke Zegers and Jelle van Gup. The first draft of the manuscript was written by Niek Kok, and all authors commented on previous versions of the manuscript. All authors read and approved the final manuscript.

\section{Funding}

The research was supported by ZonMw, Project Number 516012513.

\section{Compliance with ethical standards}

\section{Conflicts of interest}

This manuscript has not been published elsewhere and is not submitted simultaneously for publication elsewhere. There are no relevant conflicts of interest.

\section{Ethics approval}

Compliance with ethical standards. Due to circumstances, written consent was gathered by email.

\section{Publisher's Note}

Springer Nature remains neutral with regard to jurisdictional claims in published maps and institutional affiliations.

Accepted: 15 May 2020

Published online: 28 May 2020

\section{References}

1. Litz BT, Stein N, Delaney E, Lebowitz L, Nash WP, Silva C, Maguen S (2009) Moral Injury and moral repair in war veterans: a preliminary model and intervention strategy. Clin Psychol Rev 29:695-706. https://doi. org/10.1016/j.cpr.2009.07.003

2. Molendijk T (2018) Toward an interdisciplinary conceptualization of moral injury: from unequivocal guilt and anger to moral conflict and disorientation. New Ideas Psychol 51:1-8. https://doi.org/10.1016/j.newideapsy ch.2018.04.006

3. Jinkerson JD (2016) Defining and assessing moral injury: a syndrome perspective. Traumatology 22(2):122-130

4. Stovall M, Hansen L, Van Ryn M (2020) A critical review: moral injury in nurses in the aftermath of a safety incident. J Nurs Scholarsh. https://doi. org/10.1111/jnu.12551

5. Fumis RRL, Amarante GAJ, Fátima Nascimento A, Vieira Junior JM (2017) Moral distress and its contribution to the development of burnout syndrome among critical care providers. Ann Intensive Care. https://doi. org/10.1186/s13613-017-0293-2 